\title{
MÉSSZEL KEZELT TALAJOK TEHERBíRÁSÁNAK VIZSGÁLATA CBR-ELJÁRÁSSAL
}

\author{
Primusz Péter, Kalicz Péter, Kisfaludi Balázs és Péterfalvi József \\ Soproni Egyetem, Erdőmérnöki Kar Geomatikai, Erdőfeltárási és Vizgazdálkodási Intézet
}

\begin{abstract}
Kivonat
A kutatásban kísérletsorozatot terveztünk, arra keresve a választ, hogy különböző talajoknál különböző víztartalom és mészadagolás mellett a CBR-eljárással mekkora teherbírásnövekedést lehet kimutatni, valamint 4 napos áztatást követően mennyire csökkennek le ezek az értékek. A kérdés megválaszolásához 4 féle talajt vizsgáltunk meg, talajonként 6 féle vízadagolás, 4 féle mészadagolás és 3 féle pihentetési idő mellett készítettünk próbatesteket. A kísérletsorozat kimutatta, hogy a vizsgált talajok mindegyike alkalmas mészstabilizációs rétegek épitéséhez. A kezelés hatására CBR teherbírásuk nagymértékben növekedik. A kezeletlen és a kezelt minták elárasztásával, majd az alakváltozás és teherbírás mérésével igazolható, hogy a mésszel kezelt talajok vízérzékenysége jelentősen lecsökken. A talajminták adatain sikeresen alkalmaztuk a regressziós fa módszerét. Segítségével olyan szabályokat fogalmaztunk meg a várható teherbírásra, amelyek a gyakorlat számára is jól hasznosithatók. A kutatás eredményei tovább erősítik azt a felvetést, hogy erdészeti- és mezögazdasági utak esetén a mésszel stabilizált talajrétegek beszámíthatók a pályaszerkezet teherbíró részébe.
\end{abstract}

Kulcsszavak: mész, stabilizáció, CBR\%, teherbirás, regressziós fa, áztatás.

\section{DETERMINING THE BEARING CAPACITY OF LIME-TREATED SOILS BY THE CBR METHOD}

\begin{abstract}
In this research a set of tests were performed to determine the effect of lime addition and water content on the bearing capacity of cohesive soils. The bearing capacity was measured by the CBR method. Four types of soils were included in the research. Soil samples were prepared from each type by 6 different water content, 4 dosage of lime addition and 3 duration of curing time. It was found, that each soil is suitable for the construction of lime-stabilized pavement layers. As a result of the lime treatment the bearing capacity of each soil was increased. Repeated CBR tests were performed on the treated and untreated soil samples after 4 days of soaking. It was confirmed that the water-sensibility of the treated soils decreased significantly. A regression tree model was applied to create practice-oriented rules for predicting the bearing capacity. Our results support the idea that the bearing capacity of lime-stabilized soil layers can be counted in the total bearing capacity of forestry and agricultural road's pavement.
\end{abstract}

Keywords: lime, stabilization, CBR\%, bearing capacity, regression tree, soaking. 


\section{BEVEZETÉS}

Az erdészeti és mezőgazdasági utak célja egyaránt az, hogy a termeléshez szorosan hozzátartozó anyagmozgatást gazdaságossá tegyék. A szállítás, mint minden közlekedési ténykedés, a szállitó eszköz és a pálya minőségének függvénye. A szállitási folyamat akkor lesz gazdaságos, ha az előbbi két tényező teljes mértékben összhangban van egymással.

Az anyagmozgatással kapcsolatos forgalmat alkotó nehézjárművek terheit a pályaszerkezet mellet az altalaj hordozza. Az útpályaszerkezetek ősidőktől legáltalánosabban használt anyaga a kő. A kőanyagok termelése, zúzása, osztályozása és helyszínre szállitása azonban meglehetősen költséges, különösen Magyarországon, ami földrajzi elhelyezkedése és geológiai viszonyai miatt kőben szegény ország. Ezért a mezőgazdasági és erdészeti útépítéseknél - környezetvédelmi és közgazdasági szempontokból is - különösen fontos megvizsgálni, hogy a helyi talaj milyen formában hasznositható.

Hazai körülmények között a kötött talajok felhasználása jelent problémát, különösen erősen csapadékos területeken. Az útépítés szempontjából a $600 \mathrm{~mm}$ feletti átlagos csapadékú vidékeket kedvezőtlennek ítéljük. Nagy csapadékesemény után a lehullott csapadék egy része mindenképpen beszivárog a talajba és kifejti a földmüre káros hatását. Az út felpuhul, és ha ilyenkor használjuk, akkor súlyosan károsodik. Az ilyen utak a megnövekedett karbantartási költségek mellet az elakadt rönkszállitó tehergépkocsik kimentésével is terhelik az anyagmozgatás költségeit.

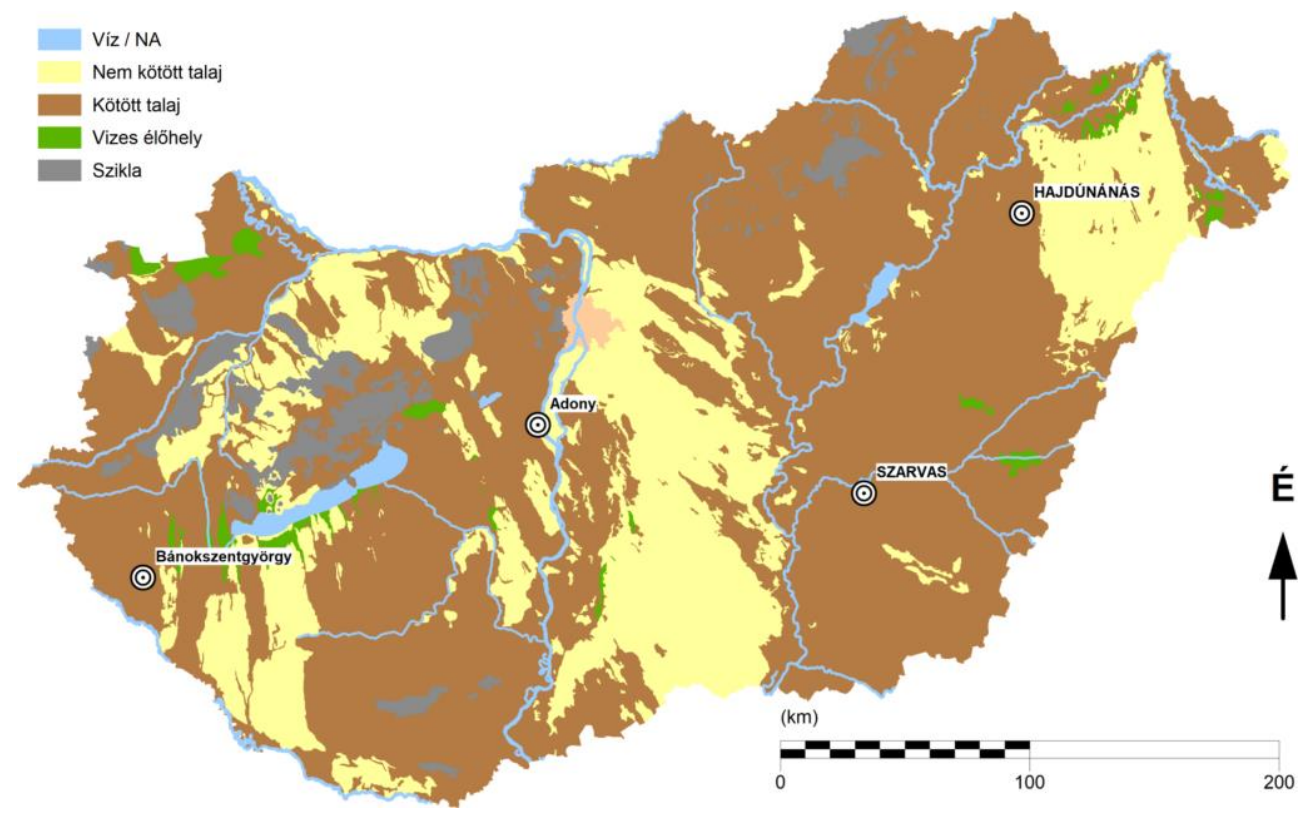

1. ábra: Magyarország talajfizikai térképe.

Figure 1: Soil texture map of Hungary. 
A felvázolt nehézségek ellenére tapasztalati tény, hogy a víztartalomtól és a tömörségtől függően minden talajnak van olyan állapota, amikor jó a teherbírása és így útpályának is megfelel. Ha a talaj kedvező tulajdonságait valamilyen eljárással állandósítani tudjuk, akkor a talaj stabilizálásáról beszélünk. A hazai talajok jelentős része (kötött és szemcsés egyaránt) megfelelő javítóanyag hozzáadásával és tömörítésével alkalmassá tehető arra, hogy az utak teherhordó pályaszerkezetének részét képezze (1. ábra). A talajstabilizációk legfőbb előnye, hogy a helyi talajt használjuk fel, ezért a helyszínre szállítandó anyagok mennyisége erősen csökken, és ezzel együtt a hagyományos épitési módokhoz képest az építési költségek is jelentősen csökkennek.

A talajstabilizációkkal kapcsolatos kutatások aktualitását napjainkban az adja, hogy a felhasznált talaj és kötőanyag keveréke minden esetben egy új anyagot eredményez. Kézdi (1967) szerint „a talajstabilizáció bizonyos mértékig még ma is „müvészet”, s csak részben mérnöki tudomány, s ebben az állitásban van is némi igazság." Ebböl következik, hogy pontos tervezői előírásokat és receptúrákat is nagyon nehéz megfogalmazni a gyakorló mérnökök számára. Ennek ellenére az USA-ban pl. a National Lime Association (NLA) szervezet kutatásokkal, laboratóriumi vizsgálatokkal és az eredmények kiértékelésével törekszik segíteni a módszer elterjedését (Szendefy 2009). Magyarországon a jellemző talajokra a megfelelő mennyiségü és minőségü kísérleti eredmények még nem állnak rendelkezésre vagy kiértékelésük még nem fejeződött be. Jelen munkában célunk egy olyan feldolgozási eljárást bemutatni, aminek a segítségével a szisztematikusan gyüjtött adatokból tervezési szabályokat vagy irányelveket lehet a gyakorló mérnökök számára levezetni.

\section{IRODALOMÁTTEKINTÉS}

A földműveket építő emberek már mintegy 5000 évvel ezelőtt törekedtek a talajok tulajdonságainak megjavitására. Ennek érdekében tapasztalataikra támaszkodva felhasználták a meszet különböző mérnöki létesitmények épitésénél. Kézdi (1979) szerint a talajstabilizáció területén elért első újkori tapasztalatok az USA-ban voltak, homok-mész keverékek formájában 1906 körül. A XX. században a 30-as évek táján a talajstabilizáció fontos tényezője lett az úttervezésnek Európában. Ebben az időszakban a hangsúly még a kivitelezésen volt, a tervezés kevesebb figyelmet kapott.

Ennek a folyamatnak az eredménye, hogy az erdészeti útépítések körében a kővel nem rendelkező erdőgazdaságoknál megindult a talajstabilizációk építése (Cornides, Szilágyi \& Nagy 1961). A kezdeti jó tapasztalatok ellenére a gépek teljesítménye korlátozta a technológia elterjedését, majd évtízedekre teljesen eltünt a hazai mérnökök látószögéböl.

A külföldi és hazai kutatásokra egyaránt jellemző, hogy azok föleg a cementes (Yang 2012) és bitumenes (Ogundipe 2014) talajstabilizációk tervezésével foglalkoznak, míg a meszes stabilizáció (Tan, Hu \& Li 2016) esetén csak az ismert talajmechanikai hatásokat és azok kémiai hátterét elemzik. 


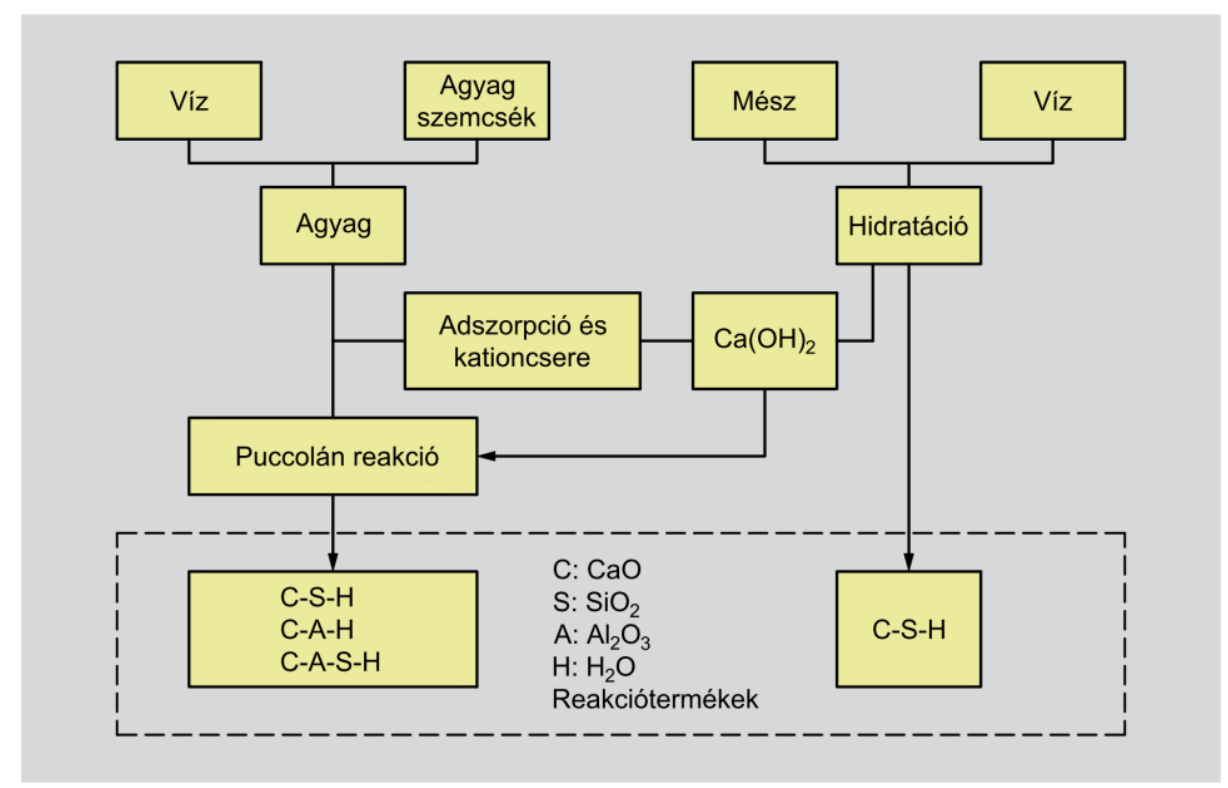

2. ábra: Kémiai reakció a talaj és a mész között (Saitoh, Suzuki \& Shirai 1985).

Figure 2: Lime-soil reaction (Saitoh, Suzuki and Shirai 1985).

Az erdészeti kutatások közül megemlítendő Pankotai és Herpay (1965) valamint Kosztka (2004) agyagtalajokkal végzett meszes talajstabilizációs munkája. Utóbbit a korszerü talajmarók és kötőanyag adagolók megjelenése inspirálta. A kutatásban a talaj-mész keveréken elvégzett szemeloszlási vizsgálatok kimutatták, hogy a mész hatására a talaj finom szemcséi összetapadnak. Minden esetben nőtt a homokliszt és homok aránya. A vizsgált talajok plasztikus tulajdonságai is jelentősen megváltoztak. Ahogy az a korábbi megfigyelések szerint várható volt, ezek a tulajdonságok a kisebb kötöttség felé tolódtak el.

A mész hatására a talajok tömörítési tulajdonságai és ezzel együtt tömöríthetöségük is előnyösen megváltozik. A legnagyobb száraz halomsürüsége lecsökken, az optimális tömörítési víztartalma megnő, a tömörítési görbe pedig ellaposodik. A mésszel kezelt próbatestek vízállósága pedig jelentősen megnő. A nemzetközi tapasztalatok megerősítése után, a meszes talajstabilizáció tervezési teherbírásának és tartósságának meghatározása került a kutatások középpontjába.

A talajstabilizációk tartósságának fontos mérőszáma, hogy teherbírásuk mennyire érzéketlen az elnedvesedéssel és fagyhatással szemben. Szendefy és Vámos (2014) kimutatta, hogy a mésszel stabilizált talajok teherbírását a víz és a fagyhatás csak kis mértékben (kb. $20 \%$ ) csökkenti, a stabilizációk vízérzéketlennek és fagyállónak minősíthetők. Vizsgálatik azt is kimutatták, hogy a stabilizált talajok az optimális víztartalom közelében, a nedves ágon bedolgozva mutatják a legjobb tartósságot. A vízérzékenységet CBR vizsgálattal, a fagyállóságot a nemzetközi szakirodalomnak megfelelően UCS vizsgálattal javasolt vizsgálni. 
Talajstabilizációk tervezésénél fontos kérdés a kötőanyag szükséges mennyiségének meghatározása. A legtöbb vizsgálatsorozat eltérő kötőanyagadagolás mellet vizsgálja a teherbírás változást, de annak mélyebb statisztikai elemzése elmarad. Ebből kifolyólag előfordulhat, hogy nem találjuk meg a jelentős (szignifikáns) teherbírás növekedést vagy csökkenést okozó adagolás értékét. Güllü (2014) munkájában a faktorelemzés segítségével vizsgálta finomszemcsés talaj és kazánhamu kötőanyag adagolásának hatását a teherbírásra. Az elemzésböl kiderül, hogy a faktorelemzés és a hatásnagyság becslése jól használható a döntéshozatalban. Végül érdemes megemlíteni Yeh (1998) munkáját aki mesterséges neurális hálók segítségével tudta előre jelezni eltérő betonkeverékek nyomószilárdságát. A bemutatott modell segítségével az egyes változók hatását is jól lehetett numerikusan vizsgálni. Az utóbbi időkben megjelent tanulmányok alapján pedig úgy látszik, hogy a gépi tanulás területén kifejlesztett eljárások és módszerek sikeresen alkalmazhatók összetett talajmechanikai jelenséges tanulmányozására is.

\section{ELMÉLETI HÁTTÉR}

\section{A talaj-mész kölcsönhatás}

A talaj és mész kölcsönhatás általánosságban ismert (2. ábra), azonban célszerü azt kissé mélyebben elemezni, mert vizsgálatainkat ezek ismeretében tervezzük, illetve a kapott eredményeket is ennek figyelembevételével értékeljük.

A mész a talajok tulajdonságainak javítását kémiai reakciókon keresztül éri el. A kémiai reakciók a mész és a talaj összekeverésekor indulnak be, és akár évtizedekig elhúzódhatnak. A meszes talajstabilizációnál lejátszódó legfontosabb kémiai reakciók: a mész oltódás (víztartalom csökkenés); a kationcsere-koaguláció; a puccolán reakció (cementáció) és a karbonátosodás (mészkő képződés). A mész és a talaj összekeverésekor a mész reakcióba lép a talajban található vízzel és az oltódás közben nagy mennyiségü hő keletkezik:

$$
\mathrm{CaO}+\mathrm{H}_{2} \mathrm{O} \rightarrow \mathrm{Ca}(\mathrm{OH})_{2}+\text { hő }
$$

A hőmennyiség párologtató (száritó) hatása miatt víz távozik a rendszerből, ami egy azonnal észlelhető hatás. A mész bekeverése után jelentkező azonnali hatást követi egy hosszú ideig tartó folyamat. Az oltott mészből (kalcium-hidroxid) a kalcium ionok $\left(\mathrm{Ca}^{2+}\right)$ diffúzió útján jutnak az agyagszemcsék éleihez, ahol felgyülnek és kicserélődnek a gyengébb potenciálú $\mathrm{Na}^{+}, \mathrm{K}^{+}$és Mg${ }^{2+}$ ionokra (Diamond \& Kinter 1965, Stocker 1972). A kationcsere hatására az agyag negatív töltésü felszínéhez kapcsolódó kalcium ionok pozitív töltése miatt több agyagszemcse kapcsolódik össze, az agyagszemcsék koagulálnak (Terrel, Epps, Barenberg, Mitchell \& Thompson 1979, Szendefy 2009). A talajba kerülő $\mathrm{Ca}(\mathrm{OH})_{2}$ hatására a talaj pH értéke erősen megnő, ennek hatására oldódásnak indulnak az agyagrészecskékben 
lévő $\mathrm{SiO}_{2}$ és $\mathrm{AlO}_{2}$ vegyületek. Kalcium-szilikát hidrátok és kalcium-aluminát hidrátok képződnek, amik az idő múlásával megszilárdulnak és a talajszemcséket cementálva ragasztják össze, ezt nevezzük puccolán reakciónak:

$$
\begin{aligned}
& \mathrm{Ca}^{++}+2(\mathrm{OH})^{-}+\mathrm{SiO}_{2} \rightarrow \mathrm{C}-\mathrm{S}-\mathrm{H} \\
& \mathrm{Ca}^{++}+2(\mathrm{OH})^{-}+\mathrm{Al}_{2} \mathrm{O}_{3} \rightarrow \mathrm{C}-\mathrm{A}-\mathrm{H}
\end{aligned}
$$

A mész, a szilikátok és aluminátok között meginduló puccolános reakciók a hidratáció után néhány nappal megindulnak és $1-5$ évig is eltarthatnak. Ezeknek a reakcióknak az eredménye a megkívánt talajmechanikai hatás, amelyet szemmel láthatóan is érzékelni lehet és talajizikai vizsgálatokkal kimutathatók. További hosszútávú reakció a karbonátosodás, amikor is a talajban megoltódott mészből a levegőben található szén-dioxid $\left(\mathrm{CO}_{2}\right)$ hatására kalcium-karbonát $\left(\mathrm{CaCO}_{3}\right)$, azaz mészkő alakul ki:

$$
\mathrm{Ca}(\mathrm{OH})_{2}+\mathrm{CO}_{2} \rightarrow \mathrm{CaCO}_{3}+\mathrm{H}_{2} \mathrm{O}
$$

Építéstechnikai szempontból ezt a folyamatot inkább kedvezőtlennek ítélhetjük meg, mert az egyesével képződő karbonát kristályok nem kapcsolódnak össze, ezért a kezelt réteg szilárdságcsökkenéséhez vezethet.

\section{A CBR-vizsgálat}

A teherbíró képességi vizsgálatoknak az elsődleges célja az, hogy a földmű és az egyes útpályaszerkezeti rétegek, illetve a teljes útpályaszerkezet terheléssel szembeni ellenállását és a deformáció nagyságát, illetve ezek változását meghatározzuk.

A CBR\% (California Bearing Ratio) a talaj teherbírásnak jellemzésére 1928-29 között Kaliforniában kidolgozott viszonyszám, amely megmutatja, hogy az adott talaj teherbírása, hogy viszonyul az összehasonlítási alapul választott szabványos tömör zúzottkő útépítési anyag teherbírásához. Laboratóriumi meghatározásánál az elökészített mintán penetrációs vizsgálatot hajtunk végre az MSZ EN 13286-47 szabvány szerint. A vizsgálat alatt egy $50 \mathrm{~mm}$ átméröjü tömör acél hengert nyomunk $1,27 \mathrm{~mm} / \mathrm{min}$ behatolási sebesség mellet a talajtestbe, és felvesszük a terhelőerő függvényében a talaj alakváltozását. A vizsgálat eredményeként kapott erő-behatolás görbéröl le kell olvasni a 2,5 mm és $5,0 \mathrm{~mm}$ behatoláshoz tartozó eröket kN-ban. Ezeket kell összehasonlítani a 100\%-os teherbírásúnak elfogadott tömör zúzottkőanyag penetrációs görbéjén a 2,5 mm, ill. az 5,0 mm benyomódást előidéző terhelőerőkkel:

$$
\mathrm{CBR}_{1}=\frac{\mathrm{F}_{2,5}}{13,2} \text { és } \mathrm{CBR}_{2}=\frac{\mathrm{F}_{5,0}}{20,1}
$$

ahol $F_{2,5}$ és $F_{5,0}$ a vizsgált anyag 2,5 mm-es és 5,0 mm-es benyomódásához szükséges erő kN-ban. A szabvány szerint a nagyobbik százalékos CBR-értéket kell választani közvetlen teherbírási indexnek. 


\section{Döntési fa}

A meszes talajstabilizációs kísérletek eredményeinek rendszerezéséhez a döntési fa (decision tree) osztályozót vezetjük be, ami egy egyszerü, de széles körben használt osztályozási módszer. Az eljárás alapötlete, hogy bonyolult összefüggéseket egyszerü döntések sorozatára vezetünk vissza. Algoritmusa egy mohó eljárás, ami felülről lefele haladva építi fel a döntési fát rekurzív módon, az „oszd meg és uralkodj” elv alapján (Han \& Kamber 2004). Bemenetként egy attribútumokkal (attributes) leírt objektumot adunk meg és a bemenetre adott válasz jósolt értékével, a döntéssel térünk vissza. A bemeneti és kimenetei attribútumok lehetnek diszkrétek vagy folytonosak. Egy diszkrét értékkészletü függvény tanulását osztályozásnak (classification), míg egy folytonos függvény tanulását regressziónak (regression) nevezzük.

A hagyományos döntési fák alapvetően osztályozási feladatok megoldására szolgálnak. A fa minden egyes „levelében” egy osztálycímke található, amely megadja, hogy a kérdéses objektum melyik osztályba tartozik (Fehér 2006). Folytonos változók becslésére is lehetőség van, ekkor a felépített fák leveleiben egy konstans függvény ad becslést az adott paraméter értékére. Az osztályozásra és elörejelzésre egyaránt használható fák a CART (Classification and Regression Tree) algoritmus családba tartoznak. A döntési fák számos előnyös tulajdonsága közül az egyik, hogy a gyökérböl a levélbe vezető út mentén a feltételek összeolvasásával könnyen értelmezhető szabályokat kapunk a döntés meghozatalára (Bodon 2010). Képesek automatikusan felismerni a lényeges változókat, ezeket a gyökér közelében, míg a kevésbé fontosokat a levelekhez közel vizsgálják. Elöfordulhat, hogy egyes attribútumok nem jelennek meg a fában, hiszen azok nem is befolyásolják a döntést.

A döntési fák felépítésének föbb lépéseit Bodon (2010) munkája alapján foglaljuk össze, további részletekről pedig az érdeklődő James et al (2013) könyvéből tájékozódhat. A fa felépítésekor a teljes tanító adatbázisból indulunk ki, ez lesz a gyökér. Keresünk egy olyan attribútumot, amely alapján jól szétválasztható a tanuló halmaz. Osztályozási feladatoknál az információnyereség elvét (entrópia csökkenés), vagy a Gini-indexet, elörejelzésnél a regressziós eltérés négyzetösszegét használják az adott csúcsnál az attribútum kiválasztásához. A szétvágást akkor tekintjük jónak, ha a keletkezett kisebb részek a magyarázandó változó szempontjából homogénebb, mint az egész halmaz a szétvágás előtt. A részekre rekurzívan alkalmazzuk az előbbi eljárást. Az algoritmus végül minden levélhez hozzárendeli a magyarázandó változó értékét, a döntést. A rekurziót akkor állitjuk meg egy ágban, ha a fa mélysége meghalad egy előírt korlátot vagy nincs olyan további vágás, amely javítani tudna az aktuális osztályozáson. Elörejelzés vagy regresszió esetén a vágás jóságának mértéke a keletkező két részre illeszthető regressziós modell illeszkedési hibája. A gyakorlatban ez azt jelenti, hogy az adott szinten végig kell próbálni az összes létező vágást az összes dimenzió mentén ahhoz, hogy el lehessen dönteni mi a legjobb vágás (Fehér 2006). Ez egy nagy dimenziószámú, illetve nagy elemszámú adathalmazon túl nagy számítást igényel. A CART algoritmusok ezért inkább bináris döntéseket (Recursive Binary Splitting, RBS) használnak az egyes csomópontokban a fa felépitésénél. 


\section{Véletlen erdő}

A véletlen erdő (random forest) egy ún. együttes (ensemble) módszer, amely a bemeneti jellemzőket manipulálja és döntési fákat használ fel alaposztályozókként. A tanulóadatokból létrehozott, de egymástól valamennyire különböző döntési fák mindegyike jósol valamit, majd szavazást tartunk, és a szavazás végeredményeként a leggyakoribb választ fogadjuk el. További részleteket Breiman (2001) munkájában olvashatunk.

Az erdő hatékonysága az egyes döntési fák számától és minőségétől (ha több fa szavaz, javul az eredmény), valamint a generált fák közötti korrelációtól (ha nő a korreláció az eredmény romlik) függ. A véletlen erdő (random forest) előnye, hogy pontos osztályozó, gyorsan lefut, több ezres dimenziójú bemenetet is képes kezelni és becsléseket ad arra, hogy mely változók fontosak. Tanulmányukban ezt az utolsó képességét fogjuk felhasználni arra, hogy a talajstabilizációt befolyásoló faktorok fontosságát számszerűsíteni tudjuk.

\section{ANYAG ÉS MÓDSZER}

Kísérleti programunk elsődleges célja, az égetett, őrölt mészporral kezelt talajok hatásmechanizmusának pontosabb megismerése volt az épitőmérnöki gyakorlat számára. Kísérleteinkkel ezért leginkább az eltérő tulajdonságú talajok teherbírására és vízérzékenységére kifejtett kedvező hatását vizsgáltuk. A kutatásban kiválasztott és vizsgált négy talajt a továbbiakban a mintavétel helységnevével azonositjuk:

1) Hajdúnánás (kód: HA), iszapos homokliszt

2) Szarvas (kód: SZV), közepes agyag

3) Adony (kód: $A D)$, iszapos homokliszt

4) Bánokszentgyörgy (kód: BA), közepes agyag

A mintavétel helyeit az 1. ábra mutatja be. A mintavételezés az MSZ 4488:1976 szabvány szerint történt. A minták mennyisége mintavételi helyenként $600-700 \mathrm{~kg}$ volt. A talajminták a TLI (Technológiai, Laboratóriumi és Innovációs Zrt.) laboratóriumaiba lettek beszállítva az alap talajmechanikai vizsgálatokhoz. A talajmintákat az elökészités alatt elöször szárítószekrényben $105^{\circ} \mathrm{C}$-on kiszárították, majd talajdarálóval finomra darálták. Az így előkészített mintákat műanyag zsákban, légmentesen lezárva tárolták. A kezeletlen talajok talajmechanikai alapvizsgálatinak eredményeit az 1. táblázat foglalja össze.

A kapott adatok alapján meghatároztuk a mészstabilizációs vizsgálatokhoz szükséges víztartalmi beállitásokat. A víztartalmi értékek az optimális tömörítési víztartalom figyelembevételével és a talajminták $I_{c}$ értéke alapján lettek kiválasztva (2. táblázat). Az adatok alapján kísérletsorozatot terveztünk, amivel arra kerestük a választ, hogy a mésszel kezelt talajok különböző víztartalom beállitások mellet, mekkora teherbírásnövekedést mutatnak az idő elörehaladtával. Ezért a vizsgált talajok próbatesteit 6 víztartalom (lásd. 2. táblázat) és négy mészadagolás $(0 \%, 2 \%, 4 \%, 6 \%)$ szintre állítottuk be. 
1. táblázat: Kezeletlen talajok talajmechanikai alapvizsgálatai.

Table 1: Basic geotechnical properties of untreated soils.

\begin{tabular}{|c|c|c|c|c|c|}
\hline \multirow[b]{2}{*}{ Vizsgálat } & \multirow[b]{2}{*}{ Szabvány } & \multicolumn{4}{|c|}{ Eredmények } \\
\hline & & Hajdúnánás & Szarvas & Adony & $\begin{array}{c}\text { Bánokszent- } \\
\text { györgy }\end{array}$ \\
\hline $\begin{array}{l}\text { Természetes } \\
\text { víztartalom }\end{array}$ & $\begin{array}{c}\text { MSZ } \\
14043 / 6-80\end{array}$ & $W_{\text {term }}=9,6 \%$ & $W_{\text {term }}=17,2 \%$ & $W_{\text {term }}=4,3 \%$ & $W_{\text {term }}=21,1 \%$ \\
\hline $\begin{array}{l}\text { Szemeloszlási } \\
\text { vizsgálat }\end{array}$ & $\begin{array}{c}\text { MSZ } \\
14043 / 3-79\end{array}$ & $\begin{array}{c}\mathrm{K}=1,0 \% \\
\mathrm{H}=22,9 \% \\
\mathrm{HL}=41,6 \% \\
\mathrm{I}=20,9 \% \\
\mathrm{~A}=13,7 \%\end{array}$ & $\begin{array}{c}\mathrm{K}=8,9 \% \\
\mathrm{H}=2,9 \% \\
\mathrm{HL}=19,8 \% \\
\mathrm{I}=33,9 \% \\
\mathrm{~A}=34,5 \%\end{array}$ & $\begin{array}{c}\mathrm{K}=7,9 \% \\
\mathrm{H}=17,9 \% \\
\mathrm{HL}=42,6 \% \\
\mathrm{I}=24,6 \% \\
\mathrm{~A}=7,0 \%\end{array}$ & $\begin{array}{c}\mathrm{K}=0,0 \% \\
\mathrm{H}=8,2 \% \\
\mathrm{HL}=24,8 \% \\
\mathrm{I}=41,9 \% \\
\mathrm{~A}=25,2 \%\end{array}$ \\
\hline $\begin{array}{l}\text { Konzisztencia- } \\
\text { határok }\end{array}$ & $\begin{array}{c}\text { MSZ } \\
14043 / 4-80\end{array}$ & $\begin{array}{c}W_{L}=24,6 \% \\
W_{p}=15,9 \% \\
I_{p}=8,8 \% \\
I_{c}=1,7\end{array}$ & $\begin{array}{c}W_{L}=51,1 \% \\
W_{p}=26,3 \% \\
I_{p}=24,8 \% \\
I_{c}=1,4\end{array}$ & $\begin{array}{c}W_{L}=27,2 \% \\
W_{p}=20,8 \% \\
I_{p}=6,4 \% \\
I_{c}=3,6\end{array}$ & $\begin{array}{c}W_{L}=53,0 \% \\
W_{p}=23,9 \% \\
I_{p}=29,1 \% \\
I_{C}=1,1\end{array}$ \\
\hline $\begin{array}{l}\text { Szulfáttartalom } \\
\text { meghatározása }\end{array}$ & $\begin{array}{c}\text { MSZ } \\
14043 / 10- \\
82 \\
\end{array}$ & $63,4 \mathrm{mg} / \mathrm{l}$ & $94,14 \mathrm{mg} / \mathrm{l}$ & $11,52 \mathrm{mg} / \mathrm{l}$ & $69,16 \mathrm{mg} / \mathrm{l}$ \\
\hline $\begin{array}{l}\text { Szervesanyag- } \\
\text { tartalom }\end{array}$ & $\begin{array}{c}\text { MSZ } \\
14043 / 9-82\end{array}$ & $\mathrm{I}_{\mathrm{om}}=1,8 \%$ & $\mathrm{I}_{\mathrm{om}}=2,5 \%$ & $\mathrm{I}_{\mathrm{om}}=2,3 \%$ & $I_{o m}=2,3 \%$ \\
\hline $\begin{array}{l}\text { Tömöríthetőségi } \\
\text { Proctor-vizsgálat }\end{array}$ & $\begin{array}{c}\text { MSZ } \\
14043-7 / 81\end{array}$ & $\begin{array}{c}\rho_{\mathrm{dmax}}=1,87 \mathrm{~g} / \mathrm{cm}^{3} \\
W_{\mathrm{opt}}=11,6 \%\end{array}$ & $\begin{array}{c}\rho_{\mathrm{dmax}}=1,65 \mathrm{~g} / \mathrm{cm}^{3} \\
\mathrm{~W}_{\mathrm{opt}}=19,7 \%\end{array}$ & $\begin{array}{c}\rho_{\mathrm{dmax}}=1,95 \mathrm{~g} / \mathrm{cm}^{3} \\
W_{\text {opt }}=11,6 \%\end{array}$ & $\begin{array}{c}\rho_{\mathrm{dmax}}=1,91 \mathrm{~g} / \mathrm{cm}^{3} \\
\mathrm{~W}_{\mathrm{opt}}=12,6 \%\end{array}$ \\
\hline $\begin{array}{c}\text { Talaj } \\
\text { megnevezése }\end{array}$ & $\begin{array}{c}\text { MSZ } \\
14043 / 2-79\end{array}$ & $\begin{array}{c}\text { Iszapos } \\
\text { homokliszt }\end{array}$ & $\begin{array}{l}\text { Közepes } \\
\text { agyag }\end{array}$ & $\begin{array}{c}\text { Iszapos } \\
\text { homokliszt }\end{array}$ & $\begin{array}{c}\text { Közepes } \\
\text { agyag }\end{array}$ \\
\hline
\end{tabular}

2. táblázat: $A$ kezelt talajok víztartalmi beállitásai.

Table 2: Water content of treated soil samples.

\begin{tabular}{|c|c|c|c|c|c|c|c|}
\hline \multicolumn{2}{|c|}{ Hajdúnánás } & \multicolumn{2}{c|}{ Szarvas } & \multicolumn{2}{c|}{ Adony } & \multicolumn{2}{c|}{ Bánokszentgyörgy } \\
\hline$I_{\mathbf{c}}$ & $\mathbf{W}(\%)$ & $\mathbf{I}_{\mathbf{c}}$ & $\mathbf{W}(\%)$ & $\mathbf{I c}_{\mathbf{c}}$ & $\mathbf{W}(\%)$ & $\mathbf{I}_{\mathbf{c}}$ & $\mathbf{W}(\%)$ \\
\hline 1,79 & 9 & 1,58 & 12 & 2,84 & 9 & 1,58 & 7 \\
\hline 1,56 & 11 & 1,38 & 17 & 2,37 & 12 & 1,36 & 13 \\
\hline 1,33 & 13 & 1,17 & 22 & 1,91 & 15 & 1,07 & 22 \\
\hline 1,10 & 15 & 0,97 & 27 & 1,44 & 18 & 0,86 & 28 \\
\hline 0,87 & 17 & 0,77 & 32 & 0,97 & 21 & 0,58 & 36 \\
\hline 0,64 & 19 & 0,57 & 37 & 0,50 & 24 & 0,36 & 43 \\
\hline
\end{tabular}

Rövidítések: $w_{L}$ - folyási határ, $w_{p}$ - plasztikus határ, $I_{p}$ - plasztikus index, $I_{c}$ - konzisztencia index, lom - talaj szervesanyag-tartalma, pdmax - maximális száraz halomsürüség, w - víztartalom tömeg\%-ban, wopt - optimális tömörítési víztartalom tömeg\%-ban. 
Mivel mészstabilizációkor a teherbírás-változás egy időben elhúzódó folyamat, a próbatesteket eltérő pihentetési idő ( 1 óra, 3 nap, 28 nap) elteltével terheltük meg a beállított szinteken. A kezeletlen talajminták teherbírását azonos, 1 órás pihentetés után mértük. A vizsgált próbatestek száma (N) egy talaj esetén a következőképpen alakult:

$$
N=6 \times 3 \times 3+6=60 d b
$$

Összesen tehát a kiválasztott négy talaj esetében $4 \times 60 \mathrm{db}$ mintát, azaz $240 \mathrm{db}$ kísérleti beállitást készítettünk.

A minták elkészítésekor elöre kimértük az adott keverékhez szükséges víz és mész mennyiségét. A mészadagolást tömeg\%-ban fejezzük ki, ami minden vizsgálatnál a kiszárított talaj tömegéhez viszonyítva mutatja az őrölt égetett mészpor mennyiségét. A légszáraz talajhoz hozzáadatuk a kimért mészmennyiséget, majd folyamatos keverés mellet adagoltuk hozzá a vizet. Az így kapott keveréket 90 percig állni hagytuk párazáró csomagolásban. A pihentetési idő a mész oltódásához szükséges, ami a térfogatváltozás miatt fellazíthatja, károsíthatja a korán betömörített mintákat (Szendefy \& Vámos 2014). A pihentetést követően $5 \times 55$ ütést alkalmazva CBR-edénybe a Proctor-vizsgálattal megegyező módon előállítottuk a próbatesteket (3. ábra). A CBR-edények végül párazáró csomagolást kaptak és az elöirt ideig tovább pihentek. A kutatásban a vizsgálatainkhoz a Carmeuse Hungária Kft. által rendelkezésünkre bocsátott CL 90 minőségü égetett, örölt mészport használtuk fel. Az egyes keverékek víztartalom beállítását utólagos mintavétellel ellenőriztük. A tervhez képest $\pm 0,5 \%$-os eltérést tapasztaltunk.

A pihentetési idő leteltével elvégeztük a minták felső és alsó síkján a szabványos CBRvizsgálatot (4. ábra). A szabvány szerint a 2,5 mm-es és $5,0 \mathrm{~mm}$-es benyomódásához tartozó CBR-értékek közül a nagyobbikat kell választani, de ez sokszor csak felesleges bizonytalanságot ad az eredményekhez. Ezért a későbbi elemzéseink számára mind a két értéket megtartottuk.

A CBR-vizsgálatok által nyert adathalmazból adatbázist építettünk. Első lépésként az adatbázisba foglalt vizsgálatok eredményeit dolgoztuk fel grafikusan. Ábrázoltuk a CBR\% értéket a víztartalom ( $w[\%])$, a mészadagolás (b[\%]) és a pihentetési idő (t[h]) függvényében.

A teherbírásváltozás bemutatására exponenciálishoz hasonló függvényt illesztettünk az adatokra a legkisebb négyzetek módszerével. Az alkalmazott függvény alakja:

$$
\mathrm{CBR} \%=\mathrm{a} \cdot \mathrm{w}^{\mathrm{b}} \cdot \mathrm{C}^{\mathrm{w}}
$$

ahol „a”, „,", „C" regressziós paraméterek és „w” pedig a vizsgált minta víztartalma (a talaj víztartalma a mészpor bekeverése előtt). A fenti függvény gyakorlati haszna annak rugalmasságában rejlik, hiszen az általános formában szereplő „b” és „C" paraméterektől függően a függvény sokféle alakot vehet fel. A függvényillesztés jósága nem minden keverék esetben volt kielégítő, de ennek ellenére mégis a fenti függvénynél maradtunk, mivel a mérési ered- 
mények trendjét jól visszaadta. A választott modell viszont nem volt alkalmas a faktorok hatásának elemzésére, ezért adataink részletesebb elemzéséhez felhasználtuk az $R$ nevü statisztikai szoftvercsomag mellet a scikit-learn numpy-ra és scipy-re épülő Python nyelvü adatbányászati modult is. A leíró jellegű alapstatisztikák mellet, regressziós fát és véletlen erdőt építettünk (100 fából) James et al (2013) munkája alapján.

Azért, hogy a mésszel kezelt próbatestek vízérzékenységét megítélhessük, a 28 napig pihentetett talajmintákat teljesen vízbe állítottuk, és 4 napon keresztül áztattuk. Az elárasztás alatt méroórákkal mértük a minták alakváltozását (duzzadását), majd újra CBR vizsgálatot végeztünk. Az áztatás utáni CBR értékek változását befolyásoló faktorok közötti kapcsolatok erősségére korrelációs mátrixot készítettünk.

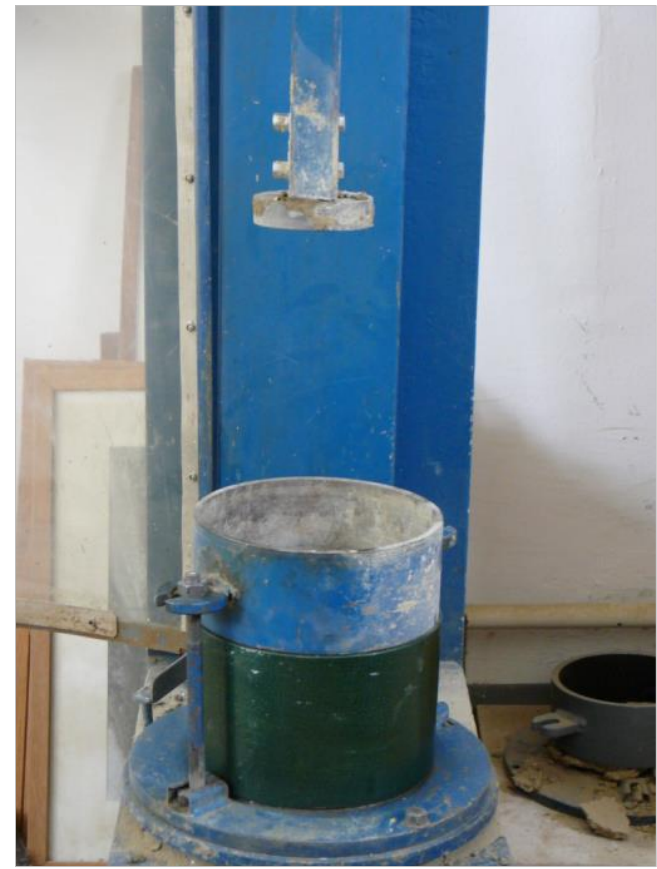

3. ábra: Proctor-féle tömöritő készülék.

Figure 3: Automatic Proctor compactor.

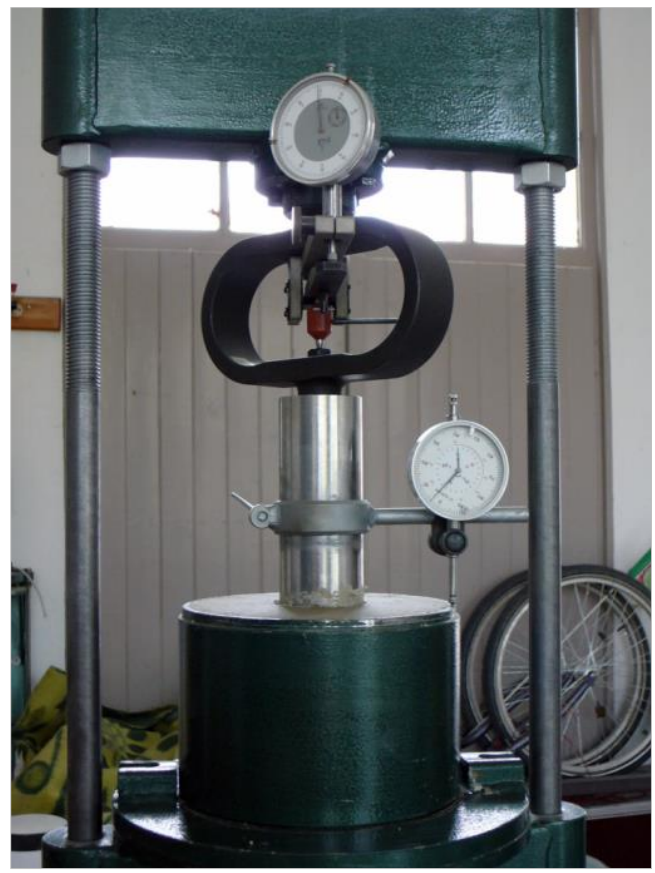

4. ábra: CBR-vizsgáló készülék. Figure 4: CBR testing apparatus.

\section{EREDMÉNYEK ÉS ÉRTÉKELÉS}

A CBR\% értékek grafikus feldolgozásakor elkésztett ábrasorozatokból most csak a Bánokszentgyörgyröl származó közepes agyagtalaj eredményeit mutatjuk be, 28 nap pihentetés után. A kiragadott mintákat bemutató 5 . ábrán keresztül jól lehet szemléltetni a mészstabilizáció teherbírásnövelő hatását. 
A kezeletlen agyagtalaj alacsony víztartalom mellett ( $\mathrm{w} \% \leq 10 \%)$ a száraz ágon igen magas CBR\% értéket képes produkálni. A víztartalom kismértékủ növekedése $(+10 \%)$ viszont már jelentősen lecsökkenti az elérhető CBR\% értékét.

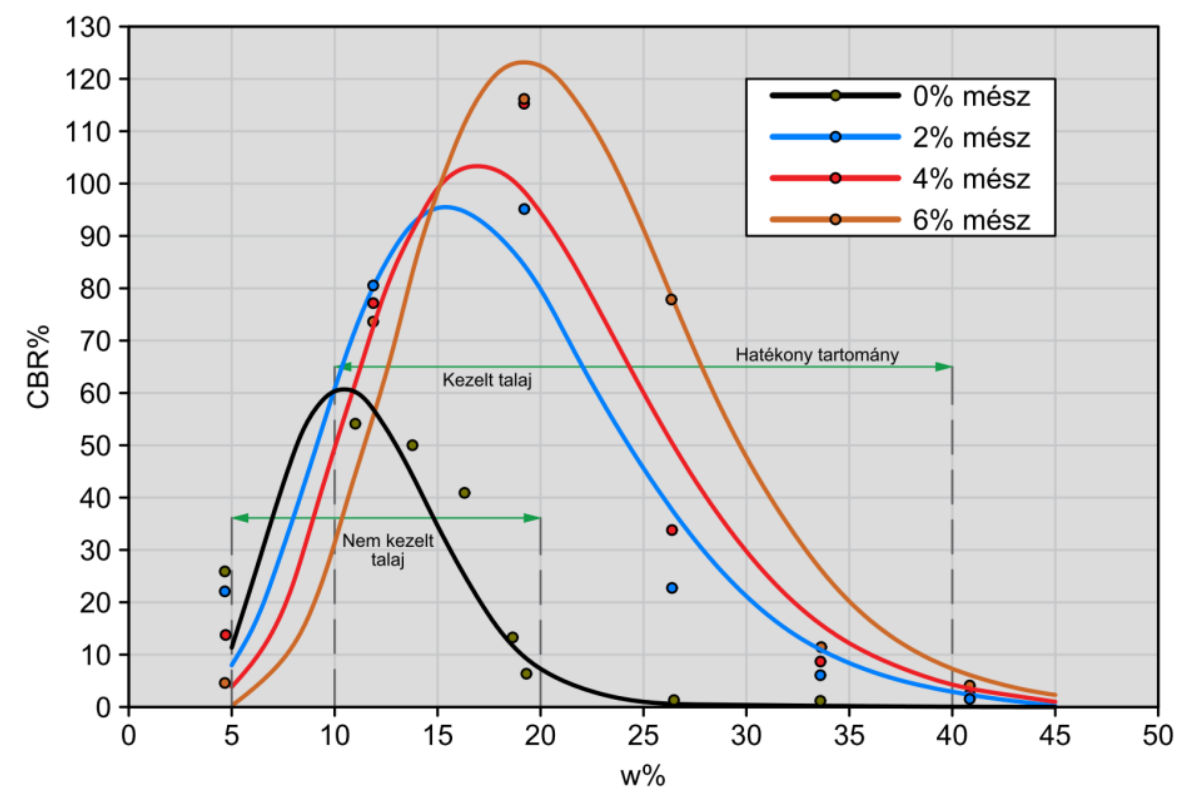

5. ábra: Bánokszentgyörgyről származó közepes agyagtalaj (pihentetés 672 óra).

Figure 5: Clay of intermediate plasticity from Bánokszentgyörgy, Hungary (672 hours of curing time).

A mészstabilizáció teherbírás növelő tulajdonsága a száraz ágon nem jelentkezik. A teherbírás nem nö, hanem csökken, a kezeletlen talaj értéke alatt marad.

A vizsgált agyagtalaj természetes nedvességtartalma $w=20 \%$ volt, ami a kísérletek szerint 4-5 CBR\% elérhetö teherbírást jelent. A mésszel kezelt talaj teherbírása ugyanezen a nedvességtartalomnál 100-120 CBR\%-nak adódott. A kezeletlen talaj ennél magasabb nedvességtartalom mellett teljesen elvesztette teherbírását, míg a mészstabilizáció $\mathrm{w}=40 \%$-on is CBR 4-5\%-ot mutatott.

A mészstabilizáció teherbírásnövelő hatása $\mathrm{w}=10 \%$ és $\mathrm{w}=40 \%$ nedvességtartalmak között a legszembetünőbb. Viszont a mészadagolás növelésével már nem fokozható tovább a teherbírás, ha a nedvességtartalom $40 \%$ fölött van. Ezért beszélhetünk egy ún. hatékony nedvesség tartományról, amin belül a kezeletlen és a kezelt talaj is kellö teherbírású, viszont azon túl már egyik sem tekinthető annak.

Az 5. ábráról levontható következtetések mind a négy talajra, egyesével megfogalmazhatók, de az így kapott ismeretek csak az adott talajra lesznek igazak.

Azért, hogy általánositani tudjuk a szabályokat a gyakorlat számára, meg kellet keresnünk a hasonlóságokat az egyes talajok viselkedésében. 
A négyféle talaj CBR\% dobozábrája alapján egyböl látszik, hogy két fő csoportra lehet bontani a talajokat (6. ábra). Így a Hajdúnánás (HA) és Adony ( $\mathrm{AD}$ ) iszapos homokliszt talajok, valamint a Szarvas (SZV) és Bánokszentgyörgy (BGY) közepes agyag talajok alkotnak egy-egy csoportot. Ez megfelel a talajazonositással kapott eredménynek. A Hajdúnánás közelében vett iszapos homokliszt talaj kicsit nagyobb teherbírást mutat, mint az adonyi. Ez valószínüleg a magasabb agyagfrakcióval $(A=13,7 \%)$ magyarázható.

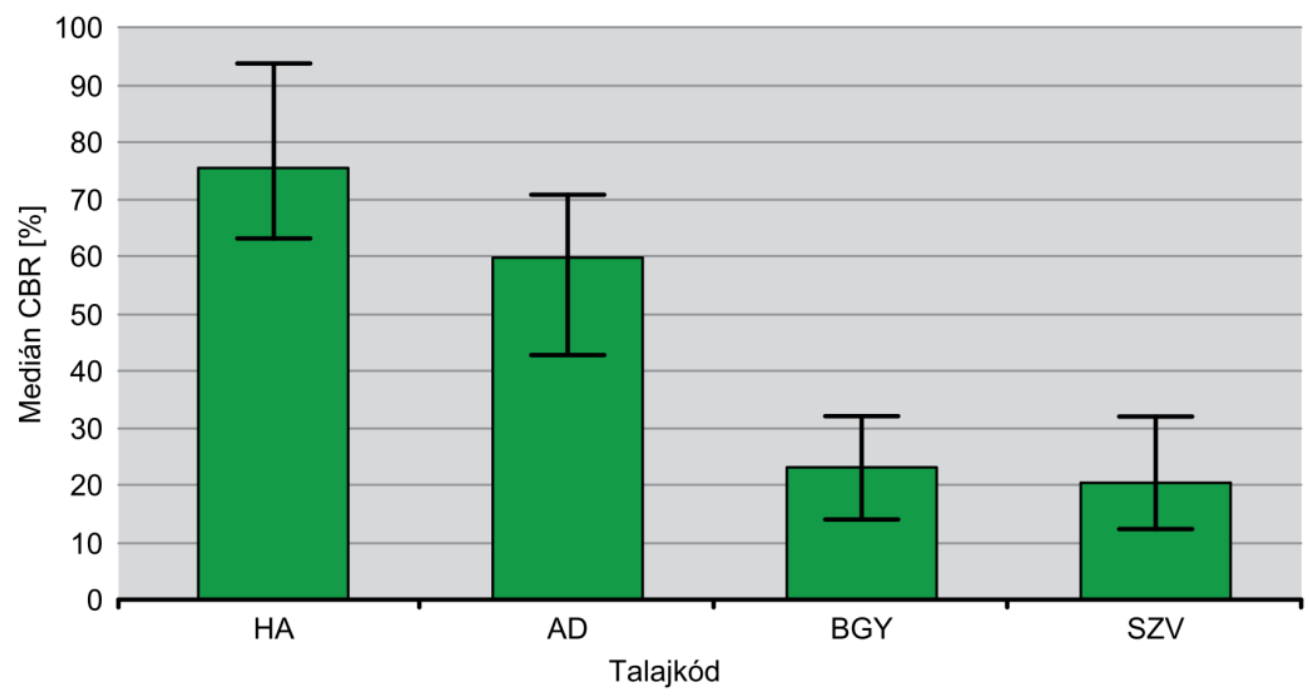

6. ábra: A négyféle talaj CBR\% dobozábrája (box-plot).

Figure 6: CBR\% range of the four tested soil types.

A teherbírás változás szabályainak és a változók közötti interakciók megismeréséhez regressziós fát készítettünk. Első lépésben a $C B R \%$-ot csak a mészadagolás ( $b \%$ és a talajfajta alapján jósoltuk. A 7. ábrán jól látszik, hogy a talajok valóban két nagy csoportra bonthatók. Az SZV és BGY kódú talajok esetén a mészadagolásnak nincs nagy szerepe ( $b \% \geq 1 \%$ ), ezzel szemben a HA és AD kódú talajoknál már érdemes azt növelni a nagyobb teherbírás érdekében ( $b \% \geq 3 \%$ ). A következő lépésben bevettük a pihentetési időt a faktorok közé, ezt mutatja be a 8. ábra. A pihentetési idő közelebb van a fa gyökeréhez, mint a mészadagolás, ezért a teherbírás növelésben nagyobb a szerepe. A talajok közül a Hajdúnánási talaj esetében van különösen nagy szerepe a pihentetési időnek. Utoljára vettük fel a vizsgált faktorok közé a víztartalmat, mivel várhatóan ennek van a legnagyobb hatása a teherbírásra. A végleges regressziós fát a 9 . ábra mutatja be. Ahogyan vártuk a víztartalom van legközelebb a fa gyökeréhez, és a teljes adathalmazt a 23\%-os nedvességtartalomnál (w\%) vágja ketté száraz és nedves ágra. Ez nagyjából megfelel a talajcsoportok beállított kísérleti víztartalmi határainak is (lásd. 2. táblázat). A fa ezután a talajfajta szerint osztja tovább az adathalmazt, végül a pihentetési idő vagy újra a víztartalom hatása kerül előtérbe. Érdekesség, hogy a mészadagolás nagysága (b\%) csak a fa mélyebb szintjein (8-10) jelenik 
meg. Ez felhívja figyelmet arra, hogy a mészadagolás nagyságát a várható nedvességtartalommal együtt célszerü meghatározni. A legnagyobb teherbírást közepes agyagtalajra az alábbi szabályok alapján kapjuk:

A w\% $<23 \%$ száraz ágon:

Ha [(víz $\geq 10 \%$ és víz $<17 \%$ ) ÉS (mész $\geq 1 \%$ és mész $<5 \%$ ) ÉS (idő $\geq 37 \mathrm{~h}$ )] Akkor CBR $\%=87,13$

$A$ w $\% \geq 23 \%$ nedves ágon:

Ha [(idő $\geq 372 h$ ) ÉS (mész $\geq 5 \%$ )] Akkor CBR\% $=32,23$

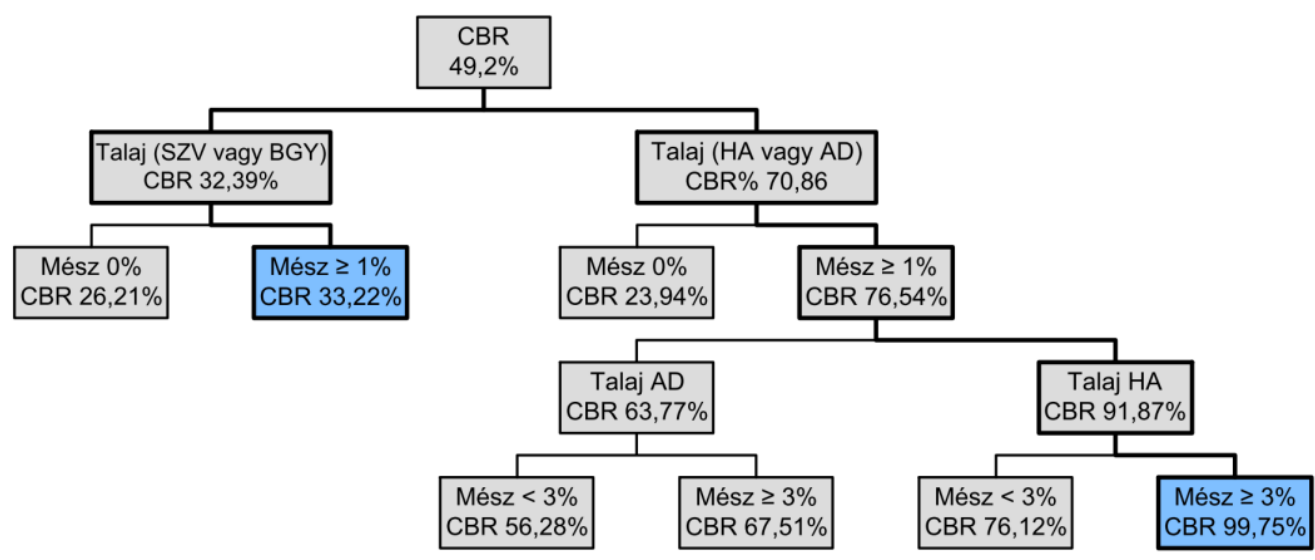

7. ábra: A talajtipus és mészadagolás hatása.

Figure 7: The effect of soil type and lime dosage (b\%) on the bearing capacity.

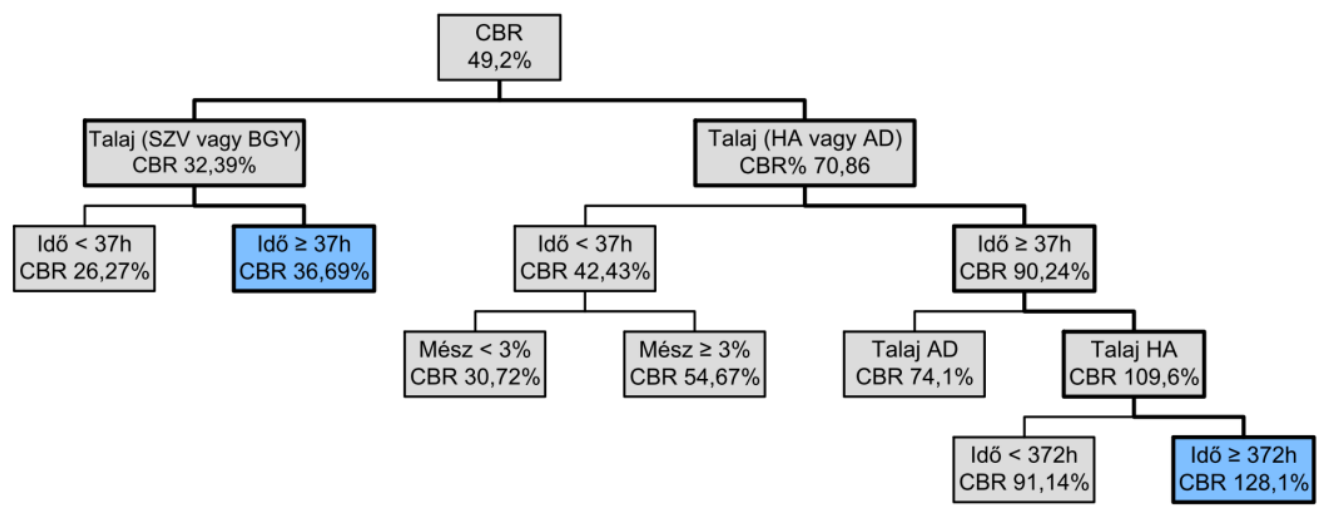

8. ábra: A talajtípus, pihentetési idő és mészadagolás hatása.

Figure 8: The effect of soil type, curing time and lime dosage $(b \%)$ on the bearing capacity. 


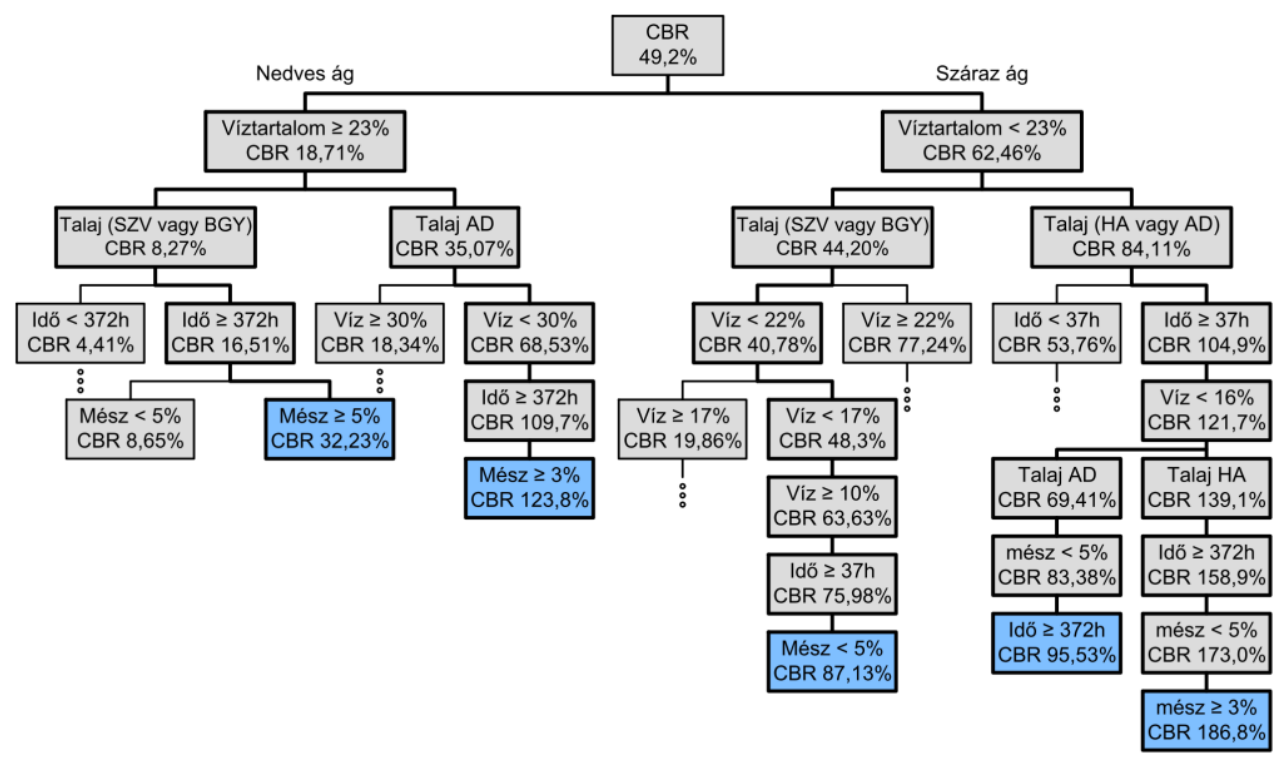

9. ábra: A talajtípus, pihentetési idő, víztartalom és mészadagolás hatása.

Figure 9: The effect of soil type, curing time, water content (w\%) and lime dosage $(b \%)$ on the.

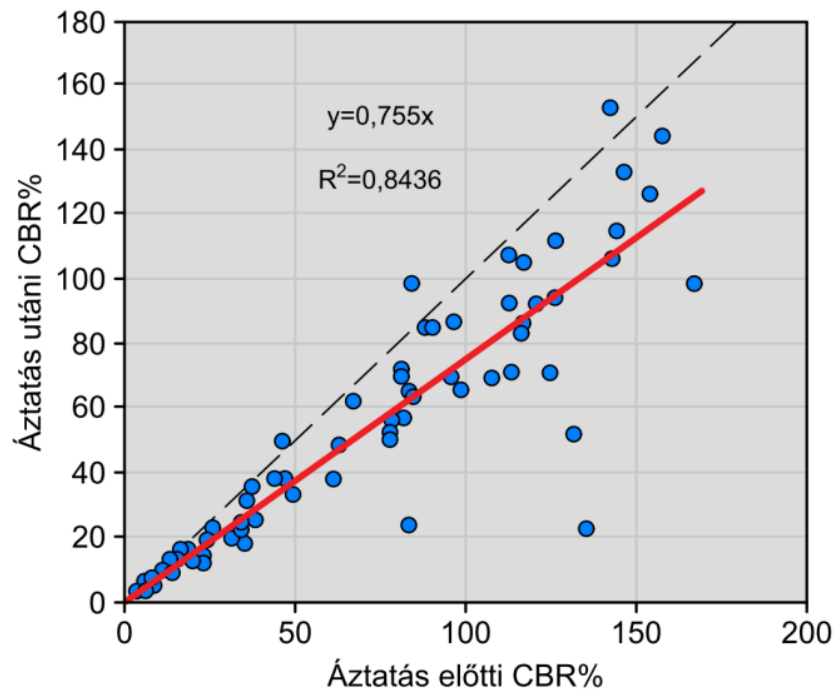

10. ábra: Az áztatás elött és után mért $C B R \%$ értékek viszonya egymáshoz.

Figure 10: Interrelation of the measured CBR\% before and after soaking the soil samples.

A száraz ágon csak egy szük nedvesség tartományon (10\%-17\%) belül érhető el a legnagyobb teherbírásérték, így ezt teherbírás szempontjából optimális víztartalomnak tekinthetjük. Ez az érték egyébként közel esik a tömörítés szempontjából kedvező optimális nedveségtartalom (Wopt) értékhez is (lásd. 1. táblázat). A mész hatása a teherbírásra már kis 
adagolásban és rövid pihentetési idő után is jól látható. A nedves ágon már jelentős mészadagolásra ( $\min .5 \%$ ) és pihentetési idöre (min. 2 hét) van szükség a maximális teherbírás eléréshez. A legnagyobb teherbírást iszapos homokliszt talajra az alábbi szabályok alapján kapjuk:

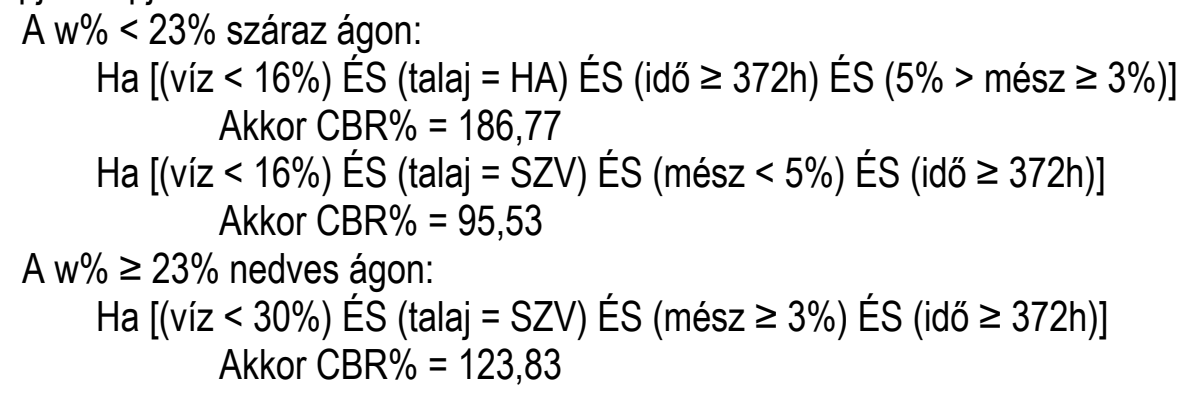

Iszapos homokliszt talajoknál a 23\%-os nedveségtartalom már nagyon magas, tulajdonképpen a kísérleti beállitások maximumát jelenti. Ezért itt nem érdemes külön tárgyalni a száraz és nedves ágat. A teherbírást 3\% és $5 \%$ mészadagolás között érdemes megválasztani, egy szük $12 \%$ (Wopt) és 16\% nedvességtartalom tartomány mellet.

A nemzetközi és hazai szakirodalom (Tárczy 2007) szerint a nagyobb kötöttségű talajok $I_{p} \geq 15 \%$ esetén a meszes kezeléstöl intenzív, míg a kevésbé kötött talajok $10 \% \leq I_{p} \leq 15 \%$ értékek között csak mérsékelt teherbírásnövekedést mutatnak.

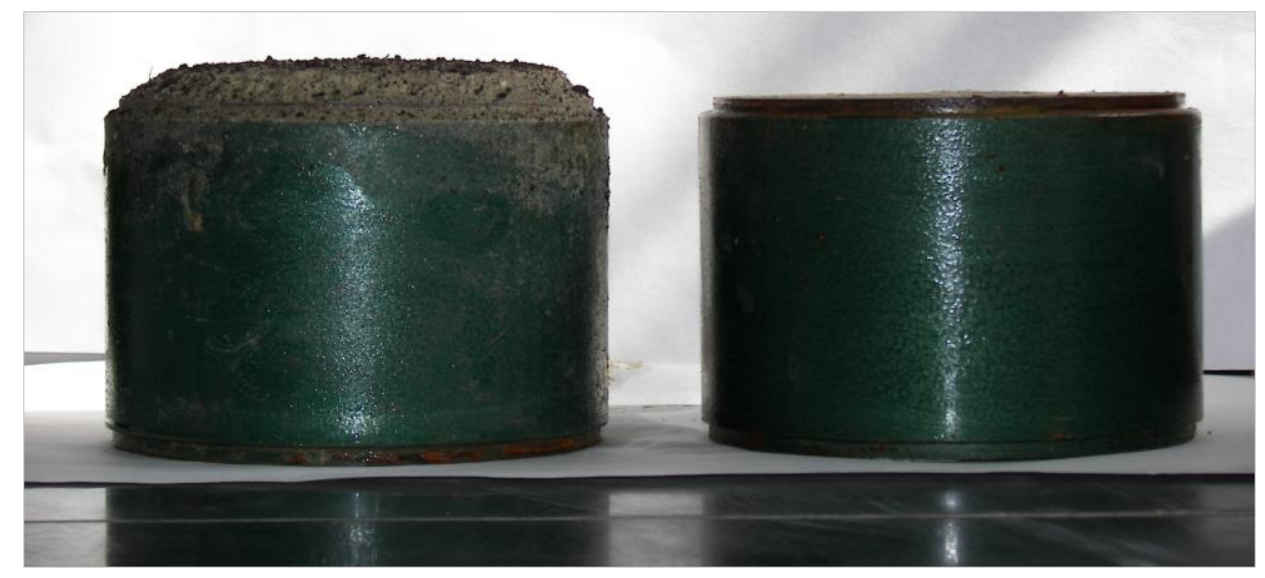

11. ábra: „Adony” talaj áztatás után, bal oldalon kezeletlen, jobb oldalon $4 \%$ mésszel kezelt minta.

Figure 11: Soil sample from Adony after soaking. Untreated (I) and 4\% lime treated (r) sample.

Bár ez a megállapítás általánosan igaz, mi kísérleteinkben ezzel szemben a legnagyobb CBR-értékeket a kevésbé kötött iszapos homokliszt talajok mutatták. Ez felhívja a figyelmet arra, hogy a plasztikus index vagy szemeloszlás alapján nem mindig lehet a megfelelő kötőanyag típust meghatározni, ezért a jövőben a többi talajfizikai jellemzőre is nagyobb figyelmet kell fordítani, például agyagásvány tartalom meghatározása metilén-kék teszttel. 
A mészstabilizációt befolyásoló faktorok fontosságát, a véletlen erdő módszer segítségével számszerüsítettük. A faktorok közül a nedveségtartalom hatása a legerősebb (65\%), majd a pihentetési idő (25\%), végül az adagolt mész mennyisége következik (10\%). Az első két hatás együtt átlagosan $90 \%$-os mértékben, míg a mészadagolás mennyisége csak $10 \%$ os mértékben tudja befolyásolni a várható teherbírást. Ez azt is jelenti, hogy stabilizáció tervezésekor és építéskor, elsősorban a víztartalom beállitásra kell nagy hangsúlyt fektetni.

A mésszel kezelt próbatestek vízérzékenységét és egyben teherbírásuk tartósságát 4 napos áztatással vizsgáltuk. Az eredmények egyértelműen igazolták a mészstabilizáció vízérzékenységre gyakorolt kedvező hatását. A természetes állapotukban kimondottan vízérzékeny talajok a mészstabilizáció hatására vízérzéketlenné válnak, és - megfelelő tömörítés esetén - teherbírásuk csak kis mértékben csökken. A kezeletlen próbatestek az áztatás hatására teherbírásukat gyakorlatilag teljesen elvesztették, telítetté váltak, így a CBR érték meghatározása bizonytalanná vált; $\mathrm{CBR} \%=1$ és $\mathrm{CBR} \%=5$ közötti értékeket kaptunk.

A mésszel kezelt próbatestek áztatás utáni CBR\% értékét befolyásoló faktorok közötti kapcsolatok erősségére korrelációs mátrixot készítettünk. A legerősseb 95\%-os kapcsolat az áztatás előtti és utáni $\mathrm{CBR} \%$ között volt. $\mathrm{A}$ többi változó erőssége, mint a víztartalom $(25 \%)$ és mészadagolás $(6 \%)$ jóval kisebbre adódott. A mésszel kezelt talajminták áztatás előtti és utáni CBR értékeit grafikusan a 10. ábra mutatja bel. Az adathalmazra illesztett lineáris modell alapján viszonylag jól becsülhető a hosszútávú teherbírásérték. Az eredmények alapján közel 25\%-os csökkenésre számíthatunk.

Az áztatás közben a minták alakváltozását elmozdulásmérő órákkal próbáltuk meg mérni, de táblázatos formában közölhető, megbízható adatsort nem tudunk közölni. Megfigyeléseink alapján kijelenthető, hogy míg a természetes állapotú talajok az elárasztás hatására jelentős alakváltozást szenvedtek (10-30 mm) duzzadtak, addig a mésszel kezelt minták alakváltozása elhanyagolható mértékü (1-2 mm) volt. A 11. ábra az „Adony” talaj kezeletlen és $4 \%$ mésszel kezelt próbatestét mutatja be, a négy napos elárasztást követően.

\section{ÖSSZEFOGLALÁS ÉS KÖVETKEZTETÉSEK}

A kísérletsorozat kimutatta, hogy a vizsgálatba bevont talajok alkalmasak mészstabilizációs rétegek épitéséhez. A vizsgált talajok viszonylag széles kötöttségi tartományt reprezentáltak, az adonyi lösztalajtól $\left(I_{p}=6 \%\right)$ a bánokszentgyörgyi közepesen kötött agyagtalajig $\left(I_{p}=29 \%\right)$. A vizsgált talajokhoz hasonló tulajdonságú talajok Magyarország jelentős részén előfordulnak, ezért a mészstabilizációs technológiát számos helyen előnyösen lehet alkalmazni.

A kezeletlen talaj, illetve a különböző mészadagolással kezelt keverékek teherbírásának jellemzésére alapvetően a CBR-eljárás alkalmazását javasoljuk.

A CBR értékek feldolgozásánál célszerűnek látszik a teherbírási adatokat a víztartalom, az idő és a mészadagolás függvényében vizsgálni. Nagyobb mintaszám esetén pedig az 
adatok elemzésére jól felhasználható a regressziós fa módszere. Segítségével olyan szabályokat fogalmazhatunk meg, ami a gyakorlat számára is jól hasznosithatók. Folyamatos adatgyüjtés mellet a talajizikai jellemzők közötti kapcsolatok felderítésére is alkalmazható.

A mészstabilizációval elérhető maximális $\mathrm{CBR} \%$ teherbírást az optimális víztartalom környezetében lehet elérni, így ez felhívja a figyelmet a beépítési víztartalom jelentőségére. A tapasztaltak szerint a száraz ágon készült stabilizációk tartóssága rosszabb, mint az optimális víztartalomnál vagy a nedves ágon készült keverékeknek. Ezért épitéskor különösen oda kell figyelni az építési víztartalomra. Ha szükséges, a többlet vizet biztosítani kell. A nedves ágon a víztartalom növekedés jobban befolyásolja a teherbírást, mint a mészadagolás mennyisége, így túlzottan elnedvesedett talajok esetében előszárítást kell végezni, akár néhány \% mész előzetes bekeverésével a megfelelő talajstabilizáció létrehozása érdekében.

A vizsgálatba bevont talajok esetén a száraz ágon, alacsonyabb mészadagolást $3 \%$ és $5 \%$ között célszerü megválasztani, azonban agyagok esetében ekkor is figyelemmel kell lenni a pH-görbéböl adódó minimum mészmennyiségre. A közepes agyagtalajok esetén a nedves ágon a minimálisan szükséges mészadagolás $\geq 5 \%$, míg iszapos homokliszt talajoknál $\geq 3 \%$. A meszes stabilizációk teherbírását minimum 14 nap után javasolt előszőr vizsgálni a kísérletek alapján.

A kezeletlen és kezelt minták elárasztásával, majd az alakváltozás és teherbírás mérésével igazolható, hogy a mésszel kezelt talajok vízérzékenysége jelentősen lecsökken, de ez nem jelenti azt, hogy teljesen érzéketlenné válnának. A hatékony víztartalom tartományt átlépve a stabilizációk már nem feltétlenül hozhatók létre, ilyenkor előszárítással célszerű a víztartalmat a stabilizáláshoz megfelelöre beállítani. Bár a megfelelő minőségben elkészülő stabilizációk elnedvesedéssel szemben ellenállók, az utak víztelenítése céljából minden esetben szükséges a körültekintően megtervezett vízelvezető rendszerről is gondoskodni.

\section{KÖSZÖNETNYILVÁNÍTÁS}

A tanulmányban bemutatott laboratórium munkához a négy különféle talajt, és a kezeletlen talajminták alapvizsgálatait a TLI Zrt. végezte 2008-ban Roszik Gábor fömérnök irányítása mellet. A meszes stabilizációs kísérleteket a Soproni Egyetem Geomatikai, Erdőfeltárási és Vízgazdálkodási Intézete a Budapesti Műszaki és Gazdaságtudományi Egyetem Geotechnikai Tanszékével közösen hajtotta végre, Markó Gergely (SoE) és Szendefy János (BME) vezetésével. Köszönet illeti Szabó Melindát és Balázs Lászlót a laboratóriumi munkákban nyújtott segítségükért. A kutatást és annak végrehajtását a Carmeuse Hungária Kft. finanszírozta.

A 2008-ban elvégzett laborvizsgálatok adatsorainak feldolgozása a "Soproni Egyetem Struktúraváltási Terve" - 32388-2/2017 INTFIN sz. projekt keretében az Emberi Erőforrások Minisztériuma támogatásával valósult meg. 


\section{IRODALOMJEGYZÉK}

Bodon F. 2010: Adatbányászati algoritmusok. Jegyzet. Budapesti Műszaki és Gazdaságtudományi Egyetem, Budapest.

Breiman L. 2001: Random Forests. Machine Learning 45(1): 5-32. DOI: 10/d8zjwg

Cornides G., Szilágyi J. \& Nagy S. 1961: Kohósalak és mész alkalmazása a simonfa-töröcskei erdei út épitéséhez. Az erdő 10(6): 244-248.

Diamond S. \& Kinter E.B. 1965: Mechanisms of soil-lime stabilization. Highway Research Record 92: 83-102.

Fehér T. 2006: A prediktív hatékonyság növelése regressziós fa algoritmussal. In: XI. Fiatal Műszakiak Tudományos Ülésszaka, 111-114. Kolozsvár.

Güllü H. 2014: Factorial Experimental Approach for Effective Dosage Rate of Stabilizer: Application for FineGrained Soil Treated with Bottom Ash. Soils and Foundations 54(3): 462-477. DOI: 10/f5966d

Han J. \& Kamber M. 2004: Adatbányászat - Koncepciók és technikák. Panem Kiadó, Budapest.

James G., Witten D., Hastie T. \& Tibshirani R. 2013: An Introduction to Statistical Learning: With Applications in R. Part of the Springer Texts in Statistics book series (STS, volume 103). Springer, New York. DOI: 10.1007/978-1-4614-7138-7

Kézdi Á. 1967: Stabilizált földutak. Akadémiai Kiadó, Budapest.

Kézdi Á. 1979: Talajmechanika II. Tankönyvkiadó, Budapest.

Kosztka M. 2004: Agyagtalajok stabilizálhatósága mésszel. Kutatási jelentés. Nyugat-magyarországi Egyetem, Erdőfeltárás Tanszék, Sopron.

Ogundipe O.M. 2014: Strength and Compaction Characteristics of Bitumen-Stabilized Granular Soil. International Journal of Scientific and Technology Research 3(9): 218-21.

Pankotai G. \& Herpay I. 1965: Erdészeti szállitástan. Mezőgazdasági Kiadó, Budapest.

Saitoh S., Suzuki Y. \& Shirai K. 1985: Hardening of Soil Improvement by Deep Mixing Method. In Proceedings of the 11th International Conference on Soil Mechanics and Foundation Engineering 3, Helsinki, Finland, 947-950.

Stocker P.T. 1972: Diffusion and diffuse cementation in lime and cement stabilized clayey soils. Australian Road Research Board Special Report 8, Melbourne.

Szendefy J. 2009: A hazai talajok szerkezetének és teherbírásának változása meszes talajstabilizáció hatására. PhD értekezés. Budapest Müszaki és Gazdaságtudományi Egyetem, Építőmérnöki Kar, Budapest.

Szendefy J. \& Vámos M. 2014: A mésszel stabilizált talajok teherbírásának tartóssága, fagyállósága. Útügyi lapok 2(11).

Tan Y., Hu M. \& Li D. 2016: Effects of Agglomerate Size on California Bearing Ratio of Lime Treated Lateritic Soils. International Journal of Sustainable Built Environment 5(1): 168-175. DOI: 10/gfbxzd

Tárczy L. 2007: Meszes talajkezelés. Közúti és mélyépitési szemle 57(2): 26-28.

Terrel R.L., Epps J.A., Barenberg E.J., Mitchell J.K. \& Thompson M.R. 1979: Soil Stabilization in Pavement Structures, a User's Manual, Volume 1: Pavement Design and Construction Considerations. U.S. Department of Transportation.

Yang H. 2012: Experimental Study on Mechanical Property of Soil-Cement. In: 2nd International Conference on Electronic \& Mechanical Engineering and Information Technology, Atlantis Press. DOI: 10.2991/emeit.2012.168

Yeh I.-C. 1998: Modeling of Strength of High-Performance Concrete Using Artificial Neural Networks. Cement and Concrete Research 28(12): 1797-1808. DOI: 10/dxm5c2

Érkezett: 2019. március 14.

Közlésre elfogadva: 2019. november 15. 